\title{
Distinct immune responses and virus shedding in pigs following aerosol, intra-nasal and contact infection with pandemic swine influenza $A$ virus, $A(\mathrm{H} 1 \mathrm{~N} 1) 09$
}

Johanneke D. Hemmink ${ }^{1 \dagger}$, Sophie B. Morgan ${ }^{1 \dagger}$, Mario Aramouni ${ }^{2,7}$, Helen Everett ${ }^{2}$, Francisco J. Salguero ${ }^{3}$, Laetitia Canini ${ }^{6}$, Emily Porter ${ }^{4}$, Margo Chase-Topping ${ }^{6}$, Katy Beck², Ronan Mac Loughlin ${ }^{5}$, B. Veronica Carr ${ }^{1}$, Ian H. Brown'ㄹ, Mick Bailey ${ }^{4}$, Mark Woolhouse ${ }^{6}$, Sharon M. Brookes ${ }^{2}$, Bryan Charleston ${ }^{1}$ and Elma Tchilian ${ }^{1 *}$

\begin{abstract}
Influenza virus infection in pigs is a major farming problem, causing considerable economic loss and posing a zoonotic threat. In addition the pig is an excellent model for understanding immunity to influenza viruses as this is a natural host pathogen system. Experimentally, influenza virus is delivered to pigs intra-nasally, by intra-tracheal instillation or by aerosol, but there is little data comparing the outcome of different methods. We evaluated the shedding pattern, cytokine responses in nasal swabs and immune responses following delivery of low or high dose swine influenza pdmH1N1 virus to the respiratory tract of pigs intra-nasally or by aerosol and compared them to those induced in naturally infected contact pigs. Our data shows that natural infection by contact induces remarkably high innate and adaptive immune response, although the animals were exposed to a very low virus dose. In contacts, the kinetics of virus shedding were slow and prolonged and more similar to the low dose directly infected animals. In contrast the cytokine profile in nasal swabs, antibody and cellular immune responses of contacts more closely resemble immune responses in high dose directly inoculated animals. Consideration of these differences is important for studies of disease pathogenesis and assessment of vaccine protective efficacy.
\end{abstract}

\section{Introduction}

Influenza A virus (IAV) is an important zoonotic pathogen that can cause substantial mortality and rapidly disseminate through economically important avian (ducks and chickens) and mammalian (human, swine and other) populations [1-3]. H1N1 and H3N2 subtypes of IAV are endemic in pigs and humans, in addition to H1N2 in pigs. Because human origin viruses or viruses containing human origin gene segments frequently adapt to transmit efficiently in pigs $[4,5]$ the pig is a source of new viruses

\footnotetext{
${ }^{*}$ Correspondence: elma.tchilian@pirbright.ac.uk

${ }^{\dagger}$ Johanneke D. Hemmink and Sophie B. Morgan contributed equally to this work

${ }^{1}$ The Pirbright Institute, Pirbright, UK

Full list of author information is available at the end of the article
}

capable of initiating epidemics or pandemics in humans of mixed swine, human and avian origin [6].

As both pigs and humans are readily infected with IAVs of similar subtype, the pig is a robust and appropriate model for investigating both swine and human disease. Like humans, pigs are outbred, and physiologically, anatomically and immunologically similar to humans. The porcine lung also resembles the human in terms of its tracheobronchial tree structure, lung physiology, morphology and distribution of receptors bound by influenza A viruses [3, 7]. Thus studies of the infection dynamics of pandemic $(\mathrm{pdm}) \mathrm{A} /(\mathrm{H} 1 \mathrm{~N} 1) 09$ origin viruses in pigs may also throw light on factors affecting transmission and infection in humans.

However very few studies have evaluated the importance of dose and route of delivery of swine influenza virus (SwIV) in experimental challenge studies. Experimentally 
SwIV is typically delivered to the airways of pigs by intranasal inoculation with a syringe $[8,9]$, intra-nasally with a mucosal atomisation device (MAD) [10-12] or by intratracheal instillation [13-17]. The intra-tracheal route is reported to result in infections that cause more severe morbidity $[13,14,18,19]$ that are a reflection of the greater virus replication in the lung, while severe morbidity is rare with intra-nasal challenge. Intra-tracheal delivery is widely used because of its reproducibility and consistency, however the virus is delivered to the lower respiratory tract (LRT) and bypasses the upper respiratory tract (URT), which is the natural route of infection. In contrast the aerosol route approximates more closely the natural route of transmission as it targets the LRT but via the URT $[20,21]$ and has been described as showing more severe clinical signs [22]. However, very few challenges have been performed using aerosol delivery. In order to determine the most relevant model for assessment of IAV pathogenesis, transmission, vaccine efficacy or therapeutic intervention, we examined whether experimental delivery of SwIV to the URT or LRT intra-nasally or by aerosol respectively, best represents natural infection. To do this we evaluated the virus shedding patterns and immune responses of pigs after intra-nasal (IN) and aerosol (AERO) challenge with different doses and compared these to animals that had become infected by contact transmission, the "natural" route.

\section{Materials and methods}

\section{Animals and influenza virus challenge}

Animal experiments were approved by the Pirbright Institute and APHA ethics committees, according to the UK Animal (Scientific Procedures) Act 1986. Eight to nine week old landrace cross, female pigs were obtained from a commercial high health status herd. All pigs used were derived from the same cohort, sourced at the same time and acclimatized for a period of 7 days. Pigs were screened for absence of IAV infection by matrix (M) gene real time RT-PCR [23] and antibody-free status was confirmed using haemagglutination inhibition (HAI) with 4 SwIV antigens. Pigs were inoculated with the strain A/ Sw/Eng/1353/09, provided by Dr Sharon Brookes, APHA (DEFRA SwIV surveillance programme SW3401). The inoculum stock was propagated in the allantoic cavities of 9-11-day-old embryonated specific-pathogen-free hens' eggs. For all serological and immunological assays, the virus was propagated in Madin-Darby canine kidney (MDCK) cells.

Groups of four pigs were challenged with either $1 \times 10^{4}$ egg infectious doses EID $_{50}$ (low dose) or groups of three pigs were challenged with $1 \times 10^{7} \mathrm{EID}_{50}$ (high) of virus. Virus delivery was performed either by aerosol (AERO) in $1 \mathrm{~mL}$ following sedation or by the intra-nasal route
(IN) using a mucosal atomization device, MAD300 (Wolfe Tory Medical) with $2 \mathrm{~mL}$ of virus administered to each nostril, of non-sedated animals. For aerosol challenge an InnoSpire Deluxe Philips Respironics nebulizer was fixed to a small-sized anaesthetic mask held over the animal's nose and mouth. The animals were sedated with $5 \mathrm{mg} / \mathrm{kg}$ ketamine hydrochloride and $1 \mathrm{mg} / \mathrm{kg}$ Stresnil: azaperone administered intramuscularly.

Two days after the high dose challenge, three naïve pigs were co-housed with the 3 AERO challenged pigs and three further naïve pigs with the 3 IN infected pigs for $48 \mathrm{~h}$, after which they were moved to separate clean rooms (experimental design in Figure 1A).

In total 8 pigs were challenged with low dose: 4 by AERO (A, B, C, D) and 4 by IN (F, G, H, I); 6 were challenged with high dose: 3 by AERO (E, J, K) and 3 by IN (L, $\mathrm{M}, \mathrm{N}$ ); and 6 were infected were co-housed with infected pigs: 3 co-housed with AERO ( $R, S, T)$ challenged pigs and 3 with IN (O, P, Q) challenged.

Animals were monitored by observing demeanour, appetite and respiratory signs such as coughing and sneezing. Body temperatures were monitored using an Identichip Biothermal microchip. Animals were euthanized at 14 days post-infection (dpi) or 16 days post-contact $(\mathrm{dpc})$ with an overdose of intravenous pentobarbital sodium.

\section{Aerosol droplet size characterization}

The average droplet size produced by each of the MAD (IN) and nebuliser (AERO) devices was characterised using laser diffraction as previously described [24]. Briefly, the devices were loaded with PBS to their specified maximum fill volumes and connected to the inlet of the droplet sizer. The device under test was turned on and run until the entire dose was delivered. Testing was carried out in triplicate.

\section{Tissue sample processing}

Four nasal swabs (two per nostril) were taken daily from day 0 until the day of euthanasia at the end of the study. The four nasal swabs from each sampling were placed together into $2 \mathrm{~mL}$ of Leibovitz medium (Gibco), containing $1 \%$ foetal bovine serum (FBS) and 1\% penicillin/ streptomycin. The tubes containing the swabs were agitated, swabs were removed, and the supernatant was aliquoted and stored at $-80{ }^{\circ} \mathrm{C}$ for subsequent analysis.

Clotted and heparin anticoagulated blood samples were taken before the challenge and at $4,7,11,14 \mathrm{dpi}$ for the animals infected with a low dose of virus and at 3 , 7, 10 and 14 dpi for animals infected with a high dose of virus, blood was taken from contact animals at 2, 5, 9, 12 and $16 \mathrm{dpc}$. For PBMC isolation heparinised blood was diluted 1:1 in PBS before density gradient centrifugation 


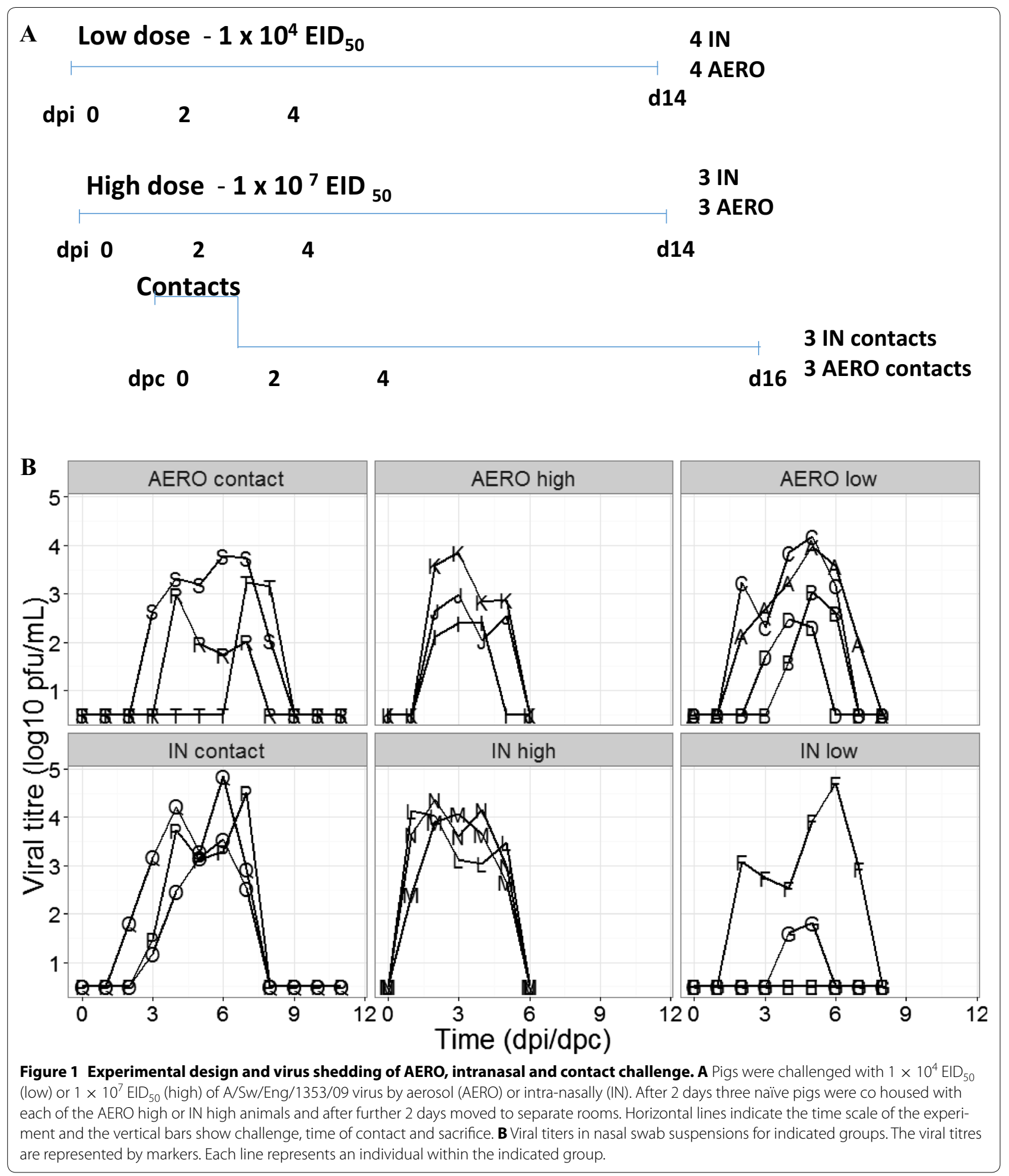

at $1200 \times g$ for $30 \mathrm{~min}$ over Histopaque ${ }^{\circledR} 1.083 \mathrm{~g} / \mathrm{mL}$ (Sigma-Aldrich). PBMC were harvested from the interface, washed in PBS and contaminating red blood cells lysed using ammonium chloride lysis buffer, washed again and cryopreserved in FBS (Gibco) with $10 \%$ (v/v) DMSO (Sigma).

Broncho-alveolar lavage (BAL) was performed post mortem, by washing the lung with $250 \mathrm{~mL}$ of PBS and 
harvesting $100 \mathrm{~mL}$ of the fluid. BAL cells were isolated by centrifuging the lavage fluid at $800 \times g$ for $15 \mathrm{~min}$, supernatant was aliquoted and frozen for antibody detection, the cell pellet was washed in PBS, filtered twice using a $70 \mu \mathrm{M}$ cell strainer and cryopreserved. Tracheo-bronchial lymph nodes (TBLN) were dissected at post mortem, cut into $1-5 \mathrm{~mm}$ pieces, before further dissociation into a single cell suspension using the GentleMACS Octo (Miltenyi), and C tubes (Miltenyi) with $3 \mathrm{~mL}$ of complete medium RPMI (Gibco) supplemented with $10 \% \mathrm{FBS}$ and penicillin/streptomycin. The cell suspension was filtered using a $70 \mu \mathrm{M}$ cell strainer and washed in PBS. All cells were cryopreserved in FBS with $10 \%$ DMSO at a minimum concentration of $1 \times 10^{7}$ cells $/ \mathrm{mL}$.

\section{Virus titration in nasal swabs}

Viral titres in nasal swab suspensions were determined by plaque assay on MDCK cells. Duplicate samples were tenfold serially diluted and $100 \mu \mathrm{L}$ medium added to confluent MDCK cells in 12 well tissue culture plates. After $1 \mathrm{~h}$, the plates were washed and overlayed with $2 \mathrm{~mL} \mathrm{1:3}$ $2 \%(\mathrm{w} / \mathrm{v})$ agarose:medium. Plates were incubated at $37^{\circ} \mathrm{C}$ for $48 \mathrm{~h}$ and plaques visualized by staining the monolayer with $0.1 \%(\mathrm{v} / \mathrm{v})$ crystal violet.

Viral RNA levels in nasal swabs were also quantified by RRT-qPCR by amplification of the M gene. RNA was extracted from $140 \mu \mathrm{L}$ swab suspension using the QIAamp viral RNA mini kit and Biorobot extraction (Qiagen) according to the manufacturer's protocol. The assay conditions used were as previously described [25]. Viral RNA present per $\mathrm{mL}$ of nasal swab suspension was correlated to relative equivalent units (REU) of infectious virus per millilitre using a ten-fold dilution series of RNA purified from infective allantoic fluid and using an interrun standard containing RNA equivalent to a known EID $_{50}$ titre of A/sw/Eng/1353/09.

\section{Pathological examination of lungs}

To assess the lung pathology groups of 4 pigs were also challenged with $1.5 \times 10^{5} \mathrm{pfu} / \mathrm{pig}$ of intermediate dose of MDCK-grown A/Sw/Eng/1353/09 (equivalent to $6 \times 10^{6} \mathrm{EID}_{50}$ ) by the IN or AERO routes. The MDCKand egg-grown viruses used in this study were sequenced and confirmed to be identical. The animals were humanely killed $4 \mathrm{dpc}$ with an overdose of pentobarbital sodium anaesthetic. At post mortem the lungs were removed and digital photographs taken of the dorsal and ventral aspects. Macroscopic pathology scoring was performed blind using Nikon-NIS Br software to determine the proportion of the total surface area of the lung (dorsal and ventral aspects) affected by typical influenza-like gross lesions.

\section{HAl assay}

Influenza virus specific antibody (Ab) titres in serum and BAL fluid were determined by HAI using standard protocols [11]. Briefly, H1N1 HAI antibody titres were determined using $0.5 \%$ chicken red blood cells and A/ Sw/Eng/1353/09 live antigen at a concentration of $4 \mathrm{HA}$ units/mL.

\section{IFN- $\gamma$ ELISPOT}

Frequencies of IFN- $\gamma$ secreting cells in PBMC, BAL cells and TBLN cells were determined by ELISPOT using previously cryopreserved cells. MultiScreen ${ }^{\text {TM }}$-HA ELISPOT plates (Merck Millipore), were coated with $0.5 \mu \mathrm{g} /$ $\mathrm{mL}$ of anti-pig IFN- $\gamma$, clone P2G10 (BD Pharmingen) in carbonate buffer and incubated at $4{ }^{\circ} \mathrm{C}$ overnight. The plates were washed 5 times in PBS and blocked using 4\% $(\mathrm{w} / \mathrm{v})$ milk powder in PBS for $2 \mathrm{~h}$. After 5 washes in PBS, $5 \times 10^{5}$ cells were seeded in triplicate wells and stimulated with either live MDCK-grown A/Sw/Eng/1353/09 $(\mathrm{MOI}=5$ ), medium control or $10 \mu \mathrm{g} / \mathrm{mL}$ Con A (SigmaAldrich). Plates were incubated for $40 \mathrm{~h}$ at $37^{\circ} \mathrm{C}$ in a $5 \%$ $\mathrm{CO}_{2}$ incubator, followed by five washes with PBS, $0.05 \%$ Tween20 and addition of $0.25 \mu \mathrm{g} / \mathrm{mL}$ anti-pig biotinylated IFN- $\gamma$ detection Ab, clone P2C11 (BD Pharmingen). Plates were incubated for $2 \mathrm{~h}$ at room temperature, washed 5 times and streptavidin alkaline phosphatase (Invitrogen) was added for a further $1 \mathrm{~h}$ at room temperature. Spots were visualised using alkaline phosphatase substrate kit (BioRad) and the reaction was stopped using tap water. Immunospots were counted using the AID ELISPOT reader (AID Autoimmun Diagnostika). Results were expressed as number of IFN- $\gamma$-producing cell per $10^{6}$ cells after subtraction of the average number of IFN$\gamma^{+}$cells in medium control wells.

\section{Flow cytometry}

Cryopreserved PBMC and cells from TBLN and BAL were thawed and stimulated for $12 \mathrm{~h}$ at $37{ }^{\circ} \mathrm{C}$ with live MDCK-grown virus strain A/Sw/Eng/1353/09 (MOI 6 for BAL and PBMC, MOI 0.6 for TBLN) or MDCK mock supernatant as control. GolgiPlug (BD Biosciences) was added according to the manufacturer's instructions for a further $5 \mathrm{~h}$ before intracellular cytokine staining. Cells were stained for surface markers with CD3e-PeCy5 PPT3 (AbCam), biotinylated CD4 clone MIL17 (in-house), with secondary streptavidin-APC (Southern Biotec), CD8 $\alpha$ FITC MIL12 (AbD Serotec) and Near-Infrared Fixable Live/Dead stain (Invitrogen). Cells were permeabilized using Cytofix Cytoperm (BD Biosciences) as per the manufacturer's instructions before intracellular staining (ICS) with IFN- $\gamma$ PE P2G10 (AbD Serotec). Samples were fixed in $1 \%$ paraformaldehyde before analysis using an LSR Fortessa instrument (BD Biosciences). 
Data was analysed using FlowJo v10 (Treestar), fluorescence of control samples stained with one primary antibody omitted were used to set gates. Samples were batch gated on lymphocytes based on SSCA/FSCA, followed by single cells on SSCH/SSCA. Live CD3 positive cells were analysed for expression of CD4 and CD8 $\alpha$. Boolean gating was used to determine the levels of IFN- $\gamma$ in CD8 $\alpha$ high, $\mathrm{CD} 4 \mathrm{CD} 8 \alpha$ double positive and $\mathrm{CD} 4 \mathrm{~T}$ cell subsets.

\section{Detection of cytokines}

The presence of IL- $1 \beta$, IL-4, IL-6, IL-8, IL-10, IL-12, IFN$\alpha$, IFN- $\gamma$ and TNF $\alpha$ in nasal swabs was determined using ProcartaPlex Cytokine\&Chemokine panel 1 (nineplex, Affymetrix, eBioscience) according to the manufacturer's instructions. Results were quantified on a Luminex ${ }^{\circledR}$ $200^{\mathrm{TM}}$ and cytokine and chemokine concentrations in the samples were determined using a standard curve for each cytokine (with lower limits of detection respectively $0.092,0.072,0.428,1.420,1.250,1.463,0.00,1.245$ and $2.272 \mathrm{pg} / \mathrm{mL}$ ). All results were obtained in duplicate and represented as the mean.

\section{Distribution of Evans Blue in lungs and pathological analysis after IN or AERO administration}

Evans Blue (Sigma-Aldrich), 5\% solution in PBS was administered by aerosol using either nebuliser or intranasal MAD device as described for the influenza A virus challenge above. After 20 min pigs were euthanized with an overdose of intravenous administered pentobarbital sodium. A detailed post mortem investigation of the upper and lower respiratory tract was conducted.

\section{Statistical analysis}

To analyse influenza viral kinetics we estimated the initial viral load, $V_{0}$, which is the necessary viral load at inoculation to induce the subsequent viral kinetic, the ascending slope, $s_{1}$, the time of the peak, $T_{\max }$ and the descending slope, $s_{2}$, using the segmented linear regression package called "segmented 0.5-0.0" in R 3.1 [26]. Parameter fitting was performed by maximum-likelihood method, using the log-scaled viral loads. The data was truncated to keep virus-positive samples. In addition we included two samples where the viral titre is below the limit of quantification, one before and one after the shedding period. We tested the association of the individual parameters between the dose groups (low, high, contact) or route group (AERO, IN, contact) using pairwise permutational $t$ test from the package "RVAideMemoire 0.9-55" in $\mathrm{R}$ 3.1.1. We used 1000 permutations and $p$ value was adjusted for multiple testing with the Benjamini and Hochberg method [27]. In the case of pigs which did not have a virus-positive sample on any occasion after the challenge, we performed the analysis after their exclusion. From the individual estimated parameters, we also predicted for each pig the height of viral titre peak computed as: $V_{\max }=V_{0}+s_{1}{ }^{*} T_{\max }$ and characterized the viral shedding period as the time during which viral titre is $>1$ $\log _{10}\left(\log _{10} \mathrm{PFU} / \mathrm{mL}\right)$. The start of shedding period was computed as $T_{\text {start }}=\left(1-V_{0}\right) / s_{1}$, the end of the shedding period as $T_{\text {end }}=\left(1-\left(V_{\max }-s_{2}\right)\right) / s_{2}$ and the duration of shedding period as $T_{\text {end }}-T_{\text {start }}$.

IL-6, IL-8 and IL-1 $\beta$ were used for statistical analysis as greater than half the samples assayed showed levels above the limit of quantification. The remaining cytokines: IFN $\alpha$, IFN $\gamma$, IL-10, IL12p40, IL-4 and TNF $\alpha$ had greater than $78 \%$ of their data below the lower limit of quantification. Data for IL-6, IL- 8 and IL- $1 \beta$ were transformed prior to analysis to correct for non-normality. IL- 8 was $\log _{10}$ transformed and IL- 6 and IL- $1 \beta$ were square root transformed. Data that were below the lower limit of quantification (LLOQ) were set to half LLOQ. Only data up to (and including) day 6 were included in order to standardise the analysis. Baseline samples were excluded as the time of sampling was not equivalent for all pigs. Principal components analysis (PCA) was run on the cytokine data matrix ( 20 pigs, 3 variables and 6 time points) using PC-ORD software version 6.03 (MJM software Design, Gleneden Beach, OR). PCA was used with a Euclidian distance measure after relativizing by standard deviates of the columns. The final set of components was determined using stopping procedures [28]. A second matrix was created including virus titre, day and challenge groups. Data within the second matrix was overlaid onto the final PCA to look for associations with cytokine levels. The strength of the correlation along principal component (PC) 1-2 for continuous variables was measured using Kendall's $\mathrm{T}$ nonparametric correlation coefficient. Significance of the $\tau$ correlation was determined using proc freq in SAS version 9.1.3 (SAS Institute Inc., Cary, NC). Significance of the categorical variables were assessed using Multi-response Permutation Procedures (MRPP) analysis, a nonparametric procedure for testing the hypothesis of no difference between two and more groups [29].

To describe the immune responses of each treatment group, the number of input variables was reduced using PCA (R statistical software version 3.3.0) to investigate underlaying principal components. Data from the HAI assay, IFN- $\gamma$ ELISPOT and flow cytometry were included in the analysis, virus and cytokine data were excluded. Principal components 1-5 (PC1-PC5) were submitted for analysis using individual general linear models, followed by post hoc tests using Tukey adjusted-least significant means. 


\section{Results}

Kinetics of virus shedding following aerosol, intranasal and contact infection with influenza virus

To determine the role of dose and route of infection on virus shedding and immune responses, pigs were infected with $\mathrm{A} / \mathrm{Sw} / \mathrm{Eng} / 1353 / 09$ influenza virus. They were challenged either with a low $\left(1 \times 10^{4} \mathrm{EID}_{50}\right)$ or high $\left(1 \times 10^{7} \mathrm{EID}_{50}\right)$ dose of virus either by aerosol (AERO) using a nebuliser, which generates small droplets believed to target the lower respiratory tract (LRT) or intra-nasally (IN) using a MAD, which produces large droplets believed to be mostly deposited in the upper respiratory tract (URT). Using laser diffraction, the average droplet size produced by the MAD device was measured as $105.7 \pm 14.1 \mu \mathrm{m}$. The fine particle fraction (FPF) less than $5 \mu \mathrm{m}$, i.e. the aerosol fraction considered capable of deposition in the LRT, was $0 \%$. The average droplet size produced by the nebuliser was $3.8 \pm 0.1 \mu \mathrm{m}$ with a FPF of $63.4 \%$. Groups of naïve pigs were co-housed with each of the high dose directly infected groups at $2 \mathrm{dpi}$ and moved to separate rooms after a further $48 \mathrm{~h}$ (Figure 1A). The clinical signs observed were mild and none of the pigs developed moderate or severe disease. Gross pathology was minimal in all animals at the time of sacrifice at 14 dpi or $16 \mathrm{dpc}$.

Virus was detected in the nasal swabs of all 4 animals in the AERO low group, with the start of shedding between 2 and 4 dpi (Figure 1B). However only 2 of the 4 animals in the IN low dose group shed any detectable virus. In contrast, all animals in the IN high dose group started shedding virus $1 \mathrm{dpi}$ and virus was detected until $5 \mathrm{dpi}$, while the animals in the AERO high dose started shedding virus at $2 \mathrm{dpi}$ and virus could only be detected for 3 or 4 days. Furthermore the animals in the IN high group not only started shedding virus earlier, but also shed more virus compared to the AERO high group (Figure 1B). Because all IN high animals shed more virus, all of the three IN contacts were infected and shed virus by 3 dpc. In contrast only 2 of the 3 AERO contacts shed virus at 2 and $4 \mathrm{dpc}$, while the third animal started shedding on $7 \mathrm{dpc}$, most likely a result of contact infection from one of its companions.

To analyse the kinetics of virus shedding we estimated the initial viral load, $V_{0}$, the ascending slope, $s_{1}$, the time of the peak, $T_{\text {max }}$, the descending slope, $s_{2}$, and the start and duration of viral shedding (Table 1). We also used the estimated parameters to predict the height of peak virus shedding (Additional file 1). The IN and AERO contacts were combined in one group for analysis as they represent natural infection (analysis with separate IN or AERO contacts gave similar results, not shown). The effects of either route or dose of challenge on viral kinetics were compared between the groups and with the contacts.
Analysis by route showed that $V_{0}$ was significantly different between the groups, with the IN high group showing the highest viral load, followed by the AERO high and contacts (Table 1 ). The viral load measured at $1 \mathrm{dpi}$ in the high IN group should be considered with caution as it is not possible to differentiate virus shed from input virus. The end of the viral shedding period was also significantly different between contacts and the other groups as the contacts shed until $9.3 \mathrm{dpc}$ ( $T_{\text {end }}$ ranging between $5.9 \mathrm{dpi}$ for AERO high and $7.3 \mathrm{dpi}$ for AERO low, Table 1). Analysis by dose on the other hand, indicates that the contacts are similar to the low dose pigs in all parameters except for $V_{0}$ and the end of shedding while they showed multiple significant differences from high dose animals.

We also measured virus shedding by RRT-qPCR, which gave similar results although the sensitivity was higher, resulting in molecular detection of low equivalent titres of virus in comparison to plaque assay for infectious virions. Overall there was a good agreement between viral titre measured by plaque assay and by PCR (Additional file 2), although molecular detection enabled monitoring of virus shedding kinetics over a longer duration. By RRT-qPCR, only $T_{\text {max }}$ was significantly different between groups $(p=0.01)$ with an earlier peak for pigs inoculated with high dose (2.3 dpi for IN high) than for pigs inoculated with low dose or by contact $(5.1 \mathrm{dpc})$. This is consistent with other studies demonstrating that viral titre measured by plaque assay represent infectious virus, whereas PCR measure total infectious and non-infectious viral RNA [30].

Taken together these data indicate that a lower dose is required for AERO infection compared to the dose required to establish infection by the IN route, based on the animal groups inoculated with a low dose of virus and that AERO infected animals transmit infection less efficiently, based on the animal groups inoculated with a high dose of virus. In contrast IN infection, requires a higher dose of virus to infect, but these animals start shedding one day earlier and shed more virus over the duration of virus egress. IN infected animals transmitted virus more efficiently, as all of their contacts were infected. The pattern of viral kinetics of contacts differed from all of the other directly infected groups in terms of the initial viral load and end of the shedding period. Nevertheless, the results for infection kinetics of contact animals, suggest that low dose challenge is more comparable to natural infection, in terms of viral kinetics and that AERO low delivery is more reproducible that IN low.

\section{Cytokines in nasal swabs}

Cytokines and chemokines are produced early after infection as part of the innate immune response to pathogens and therefore we determined whether the dose and 


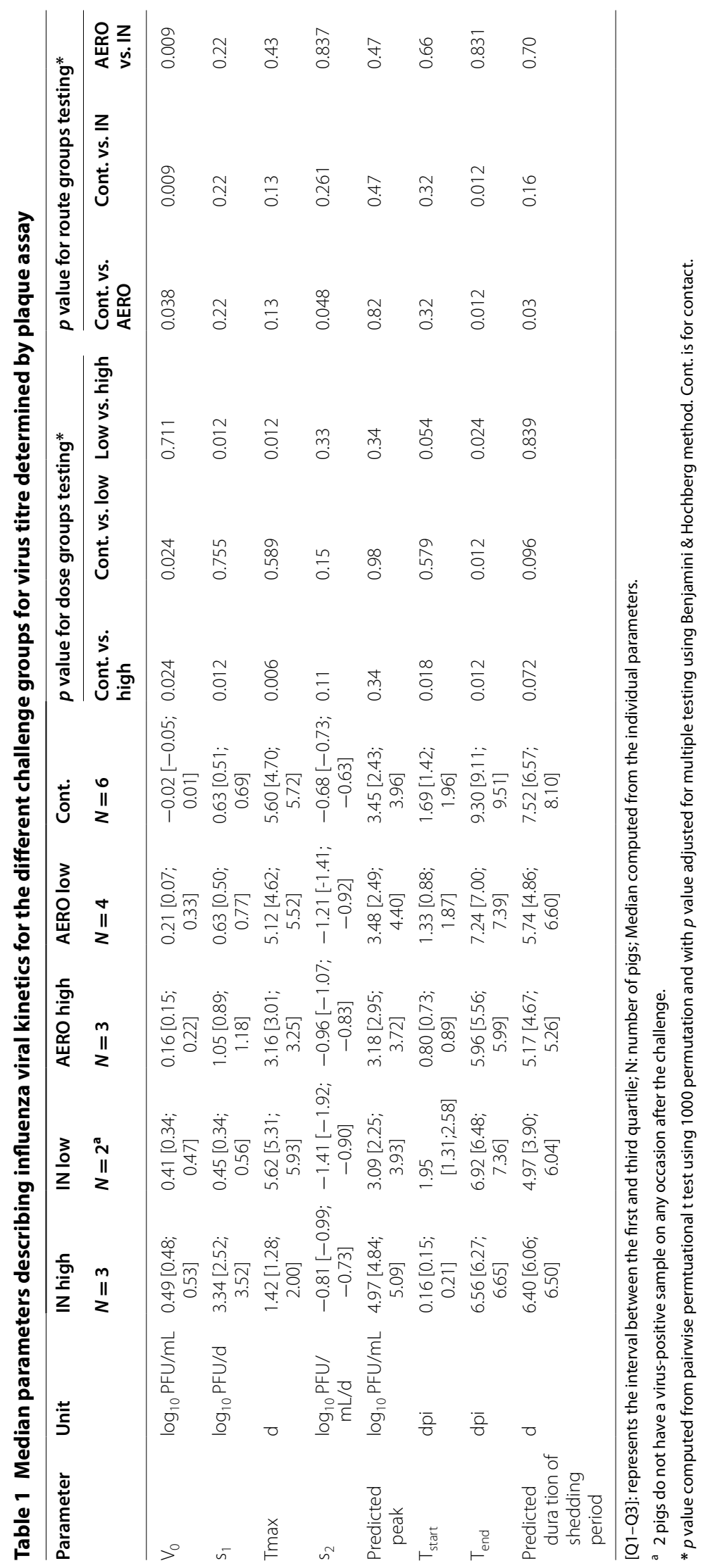


route of infection affects the innate immune response, assessed by analysing cytokine levels in nasal swabs. We measured IFN- $\alpha$, IFN- $\gamma$, TNF- $\alpha$, IL-1 $\beta$, IL-4, IL-6, IL-8, IL-10, IL-12, between 0 to $6 \mathrm{dpi}$ or dpc. However only IL-6, IL-8 and IL-1 $\beta$ were used for PCA as they were the only cytokines with greater than half of their measurements above the limit of quantification Figure 2A. We also measured cytokines in serum and BAL fluid but did not find any correlation between the responses in nasal swabs, serum and BAL fluid (Table 2).

The results of the principal component analysis (PCA) are shown using $2 \mathrm{D}$ ordination graphs of the distance between sample units which approximates increasing time (days) and viral titre (Figure 2B). PC1, which explains $78.9 \%$ of the variation in the data, is associated with high levels of IL-6 $(p<0.001)$ and IL-1 $\beta(p<0.001)$. IL-8 was associated with both PC1 $(p<0.001)$ and PC2 $(p<0.001)$. PC1 is associated with high virus titre $(p<0.001)$ and increasing time (day) $(p<0.001)$. The contacts were significantly different from the low dose directly challenged pigs by both routes of inoculation (AERO low $p=0.02$ and IN low $p=0.02$ ). However there were no differences between the contacts and the AERO high $(p=0.1)$ or IN high $(p=0.1)$ groups. For low doses there was no significant difference between the routes of inoculation $(p=0.8)$ but the AERO high and IN high groups differed significantly $(p=0.006)$.

These data showed that the cytokine profiles of the naturally infected contacts were more similar to the high dose than low dose directly challenged animals.

\section{Antibody and cellular immune responses}

We next determined whether the dose and route of infection affect the adaptive immune response. HAI titres in serum and BAL fluid are shown in Table 3. The highest HAI titers were detected in the serum of the AERO high (1:256 \pm 0$)$ and both contact groups (AERO contact 1:170.7 \pm 73.9 and IN contact 1:128.0 \pm 110.9$)$. Similarly, the highest HAI titer in the BAL fluid was detected in the AERO high animals $(64 \pm 0)$ (Table 3$)$.

We analysed the influenza A virus (1353/09 homologous stimulation) specific $\mathrm{T}$ cell responses in PBMC, BAL and TBLN by IFN- $\gamma$ ELISPOT on $14 \mathrm{dpi}$ and $16 \mathrm{dpc}$ (Figure 3A). The AERO high and low groups showed the highest virus specific PBMC responses (mean $87 \pm 59$ SFC per $10^{6}$ cells for AERO high, $72 \pm 49$ for AERO low, compared to $33 \pm 39.4$ and $30 \pm 3.5$ for IN high and IN low groups and $40 \pm 33.6$ and $36.7 \pm 14.2$ for the AERO and IN contacts). The AERO and IN contacts had the highest numbers of IFN- $\gamma$ secreting cells in BAL (respectively 159.2 \pm 120.3 and $140.9 \pm 26.8$ SFC per $10^{6}$ cells); whereas much lower responses were seen in the remaining animals (Figure $3 \mathrm{~A}$ ). In TBLN the
AERO high challenge induced the strongest IFN- $\gamma$ ELISPOT response followed by the IN contacts and AERO low, while responses in both IN groups were very low (Figure 3A).

We performed intracellular staining for IFN- $\gamma$ following in vitro stimulation with $\mathrm{A} / \mathrm{Sw} / \mathrm{Eng} / 1353 / 09$. In BAL a similar trend to the IFN- $\gamma$ ELISPOT was observed with the contacts and AERO high and low directly challenged showing higher IFN $-\gamma$ response by CD4, CD8 and CD4CD8, compared to IN challenged animals (Figure 3B).

PCA was performed with PC1 explaining $29.6 \%$ of the variation in the immune reponses of the different treatment groups and was significantly associated with group $(p=0.001)$ (Figure 3C). There were no significant differences between the contacts and both AERO and IN high dose groups (AERO high $p=0.8$, IN high $p=0.5$ ). In contrast contacts were significantly different from both low dose groups (AERO low $p=0.02$, IN low $p=0.01$ ). There were also no significance differences between the high dose groups $(p=0.2)$ or between the low dose groups $(p=1)$. None of the remaining PCAs were significantly associated with treatment group. Interestingly, when the PC loadings were considered it was apparent that intracellular cytokine production by PBMCs was positively loaded on PCA1, while IFN- $\gamma$ production by cells in the ELISPOT assay was negatively loaded, indicating that the two techniques measured different immunological parameters (Additional file 3). A possible explanation could be that other cells such as NK cells are detected in the ELISPOT, while ICS detected only CD4 or CD8 T cells. Antibody levels, as measured by HAI in BAL and serum, correlated with IFN- $\gamma$ secretion by cells in the BAL and with IFN- $\gamma$ production by $\mathrm{CD} 4^{+} \mathrm{CD} 8^{+} \mathrm{T}$ cells in the TBLN.

In summary, in contrast to the viral kinetics, the antibody and cellular immune responses of the naturally infected contacts were similar to the high dose directly infected animals and significantly different to the low dose animals. Although there was a trend for higher immune responses in the AERO high compared to the IN high animals this did not reach statistical significance.

\section{Distribution of Evans blue dye in the respiratory tract and lung pathology after AERO and IN delivery}

To establish the distribution of material after AERO and IN delivery, we examined the respiratory tract after delivery of Evans Blue dye by MAD or aerosol [31]. IN administration using a MAD device resulted in delivery of dye to the URT and the digestive tract. Dye was found within the nasal cavity mucosa, and a very small amount within the larynx and the upper trachea (Figures $4 \mathrm{~A}$ and $\mathrm{B}$ ). In addition, considerable quantities of dye could be found in 

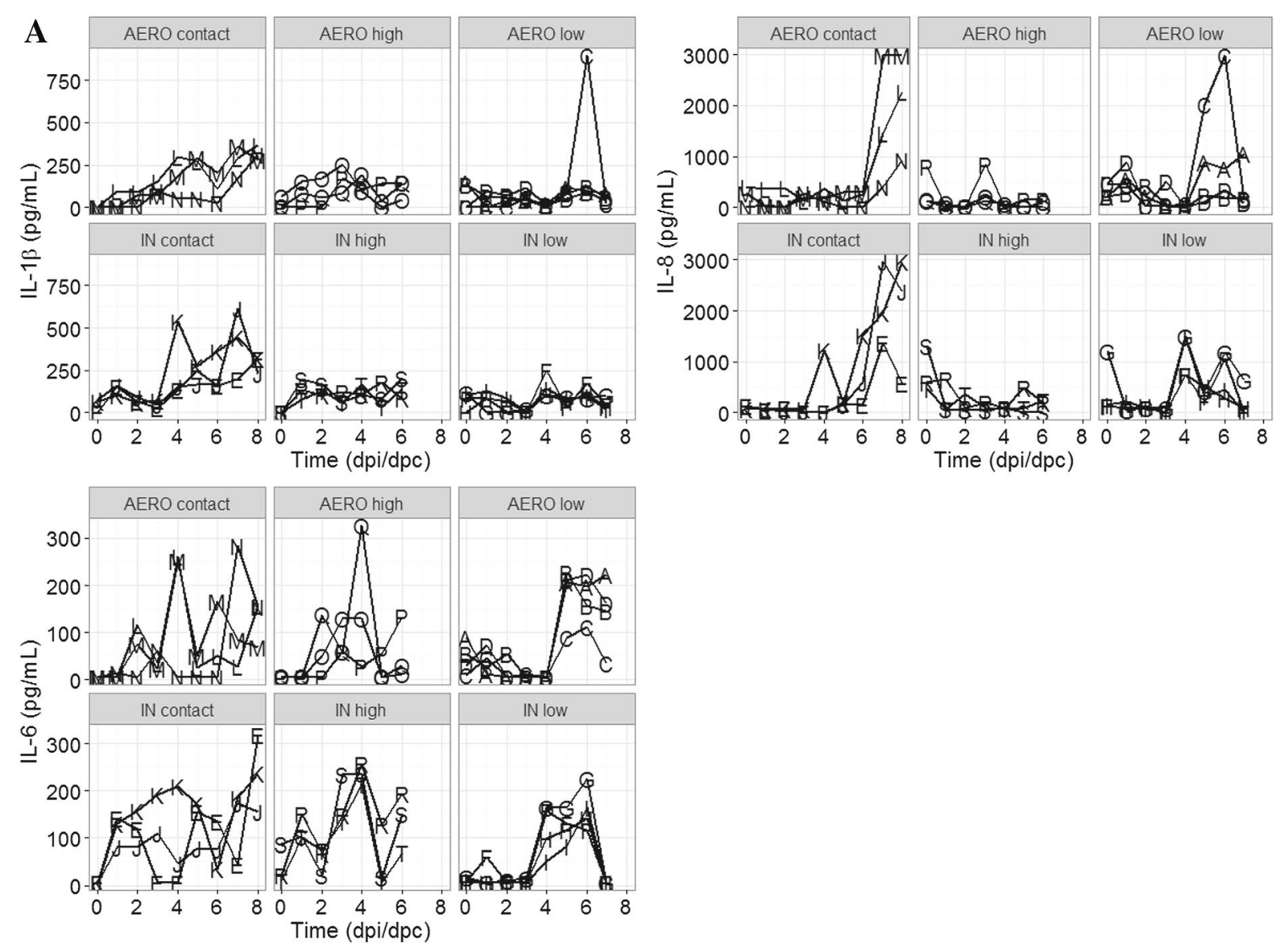

B

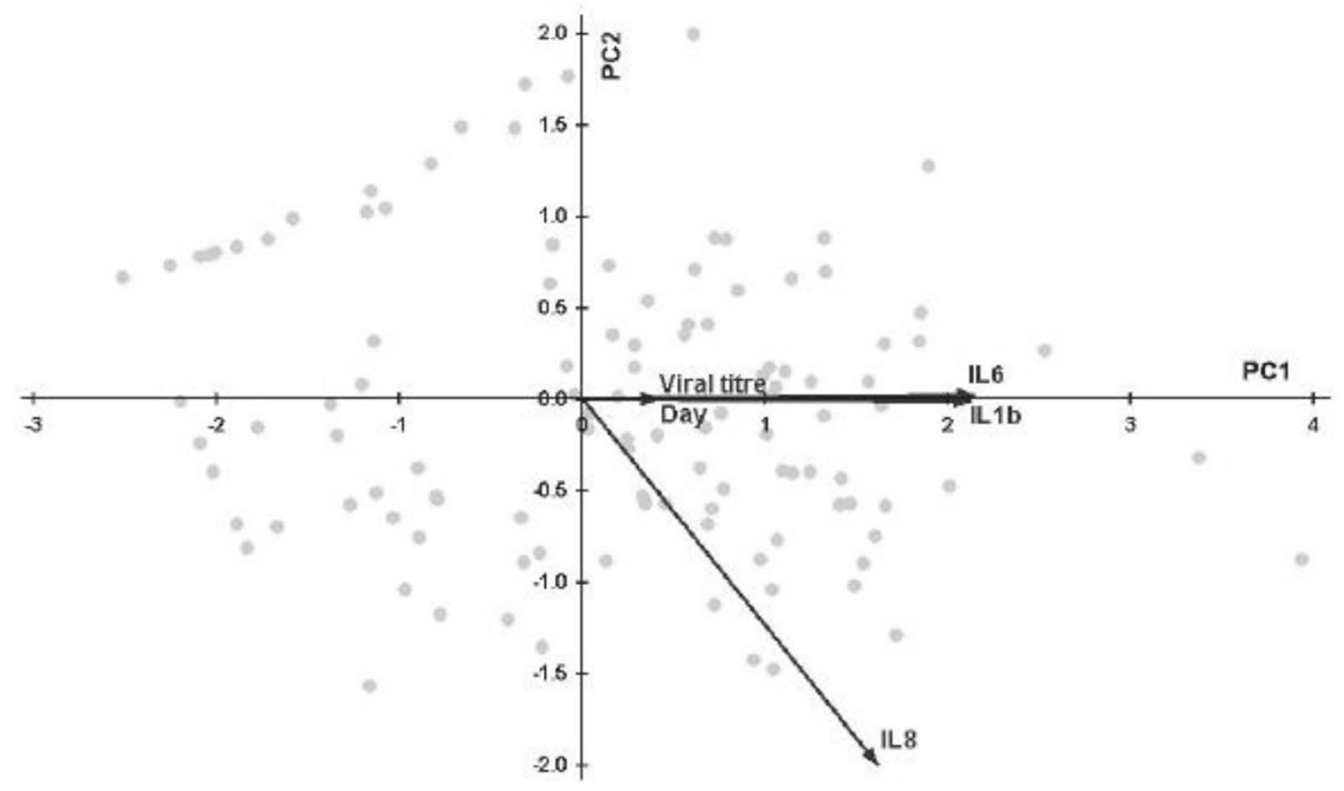

Figure 2 Cytokines in nasal swabs. A Concentrations of IL-1 $\beta, I L-6$ and IL-8 for each infected group. Each line within the graphs represents an individual within the indicated group. B Principal component (PC) analysis for IL-6, IL-8 and IL-1 $\beta$. Scatterplot with vectors showing the direction and strength of the correlation of IL-6, IL-8, IL-1 $\beta$, virus titre and time along PC1 and PC2. 
Table 2 Serum and BAL fluid $A / S w / E n g / 1353 / 09$ specific HAI titres

\begin{tabular}{|c|c|c|c|c|}
\hline \multirow[t]{2}{*}{ Group } & \multirow[t]{2}{*}{ Animal } & \multicolumn{2}{|l|}{ Serum } & \multirow{2}{*}{$\begin{array}{l}\text { BALF } \\
14 \mathrm{dpi} / 16 \mathrm{dpc}\end{array}$} \\
\hline & & $\begin{array}{l}\text { Pre-chal- } \\
\text { lenge }\end{array}$ & 14 dpi/16 dpc & \\
\hline \multirow[t]{4}{*}{ AERO low } & $A$ & 16 & 32 & 16 \\
\hline & $B$ & 4 & 64 & 32 \\
\hline & C & 8 & 64 & 32 \\
\hline & $\mathrm{D}$ & 8 & 32 & 8 \\
\hline \multirow[t]{4}{*}{ IN low } & $E$ & 16 & 64 & 16 \\
\hline & $\mathrm{F}$ & 16 & 16 & 16 \\
\hline & $\mathrm{G}$ & 8 & 128 & 16 \\
\hline & $H$ & 16 & 32 & 16 \\
\hline \multirow[t]{3}{*}{ AERO high } & 1 & 16 & 256 & 64 \\
\hline & $J$ & 8 & 256 & 64 \\
\hline & K & 16 & 256 & 64 \\
\hline \multirow[t]{3}{*}{ IN high } & $L$ & 8 & 32 & 16 \\
\hline & $M$ & 8 & 64 & 16 \\
\hline & $N$ & 16 & 128 & 16 \\
\hline \multirow[t]{3}{*}{ IN contact } & $\mathrm{O}$ & 16 & 256 & 32 \\
\hline & $P$ & 16 & 64 & 16 \\
\hline & Q & 16 & 64 & 16 \\
\hline \multirow{3}{*}{$\begin{array}{l}\text { AERO con- } \\
\text { tact }\end{array}$} & $\mathrm{R}$ & 8 & 128 & 16 \\
\hline & $S$ & 16 & 128 & 32 \\
\hline & $\mathrm{T}$ & 8 & 256 & 32 \\
\hline
\end{tabular}

HA titres were determined in serum and BAL fluid at day of sacrifice (14 or $16 \mathrm{dpc}$ ) using $4 \mathrm{HAl}$ units of $\mathrm{A} / \mathrm{Sw} / \mathrm{Eng} / 1353 / 09$ virus. Results shown are the mean of all individuals in each of the groups \pm standard deviation. Serum from pigs immunized with commercial $A(H 1 N 1)$ pdm09 vaccine Pandemrix (GSK) and challenged with A/England/195/09 (pdmH1N1) virus as previously described

[11] was used as a positive control and gave a titer of 2048.

the oral cavity, oropharynx, oesophagus (Figure 4A) and the stomach. This is consistent with the expected deposition profile of droplets of $\sim 105 \mu \mathrm{m}$ in diameter, while some excess dye also runs down the back of the throat and is swallowed. In these circumstances, any deposition in the lung would be expected to be as a result of aspiration of Evans Blue from the nasopharynx and/or larynx.
After aerosol delivery dye was found within the nasal cavity mucosa, the larynx, trachea and the entire respiratory tree from the large bronchi towards the bronchioles and including the lung parenchyma (alveoli). This is in accord with expectations, as droplets of $\sim 3.8 \mu \mathrm{m}$ in diameter would efficiently transit through the nasal cavity and into and throughout the LRT. Some deposition would be expected in the nasal cavity given the turbulent airflow through the turbinates (Figures $4 \mathrm{C}$ and D). A small amount of dye was found in the oesophagus. This is likely explained by Evans Blue again running down the back of the throat.

Because of the distinct patterns of dye distribution, we compared the lung pathology 4 days after IN and AERO administration of $\mathrm{A} / \mathrm{Sw} / \mathrm{Eng} / 1353 / 09$ influenza virus. Typical influenza-induced gross pathology was found in lungs from both groups although in the AERO the lesions were affecting different areas of the lung including the more distal parts of the lobes, while the IN, gross lesions were fewer in numbers and localised closer to the big bronchi (Figures $4 \mathrm{~F}-\mathrm{H})$. The pulmonary lesions consisted of multifocal areas of consolidation, dark in colour and consistent with necrotising bronchiolitis and atelectasis [32].

Taken together these data indicate that IN delivery distributes the dye in the URT and the digestive tract, while AERO results mainly in a wider distribution within the LRT, i.e. respiratory tree, including the lung parenchyma within the proximal and distal parts of all lung lobes. Nevertheless even with IN administration the lung does become infected albeit with a more localised distribution of lesions.

\section{Discussion}

Although aerosol is one of the natural routes of SwIV transmission, very few studies have been performed using aerosol challenge and to date there had been no headto head comparisons of IN, AERO and natural contact infection. As the pig provides a key component in studying pathogenesis of IAV and assessment of anti-viral

Table 3 Cytokine concentrations in serum and BALF of AERO and IN infected pigs

\begin{tabular}{|c|c|c|c|c|c|c|c|}
\hline \multirow[t]{2}{*}{ Group } & \multirow[t]{2}{*}{ Animal } & \multicolumn{2}{|l|}{ IL-10 } & \multicolumn{2}{|c|}{ IL-12p40 } & \multicolumn{2}{|l|}{ IL-8 } \\
\hline & & Serum & BALF & Serum & BALF & Serum & BALF \\
\hline \multirow[t]{3}{*}{ AERO high } & 1 & 0.9 & ND & 216.5 & 2.4 & 288.7 & 260 \\
\hline & J & 11.5 & ND & 184.6 & 6.1 & 239.4 & 141.9 \\
\hline & K & 20.3 & ND & 394.9 & 3.9 & 101.9 & 79.8 \\
\hline \multirow[t]{3}{*}{ IN high } & $L$ & ND & ND & 490.4 & 7.5 & 152.4 & 523.5 \\
\hline & M & ND & ND & 98.6 & 4.2 & 173.4 & 125.5 \\
\hline & $N$ & ND & ND & 472.8 & 2.2 & 218.8 & 162.6 \\
\hline
\end{tabular}

Cytokine concentrations $(\mathrm{pg} / \mathrm{mL})$ in the serum and BAL fluid at the day of sacrifice of AERO and IN high groups were determined using a commercial Luminex assay. 


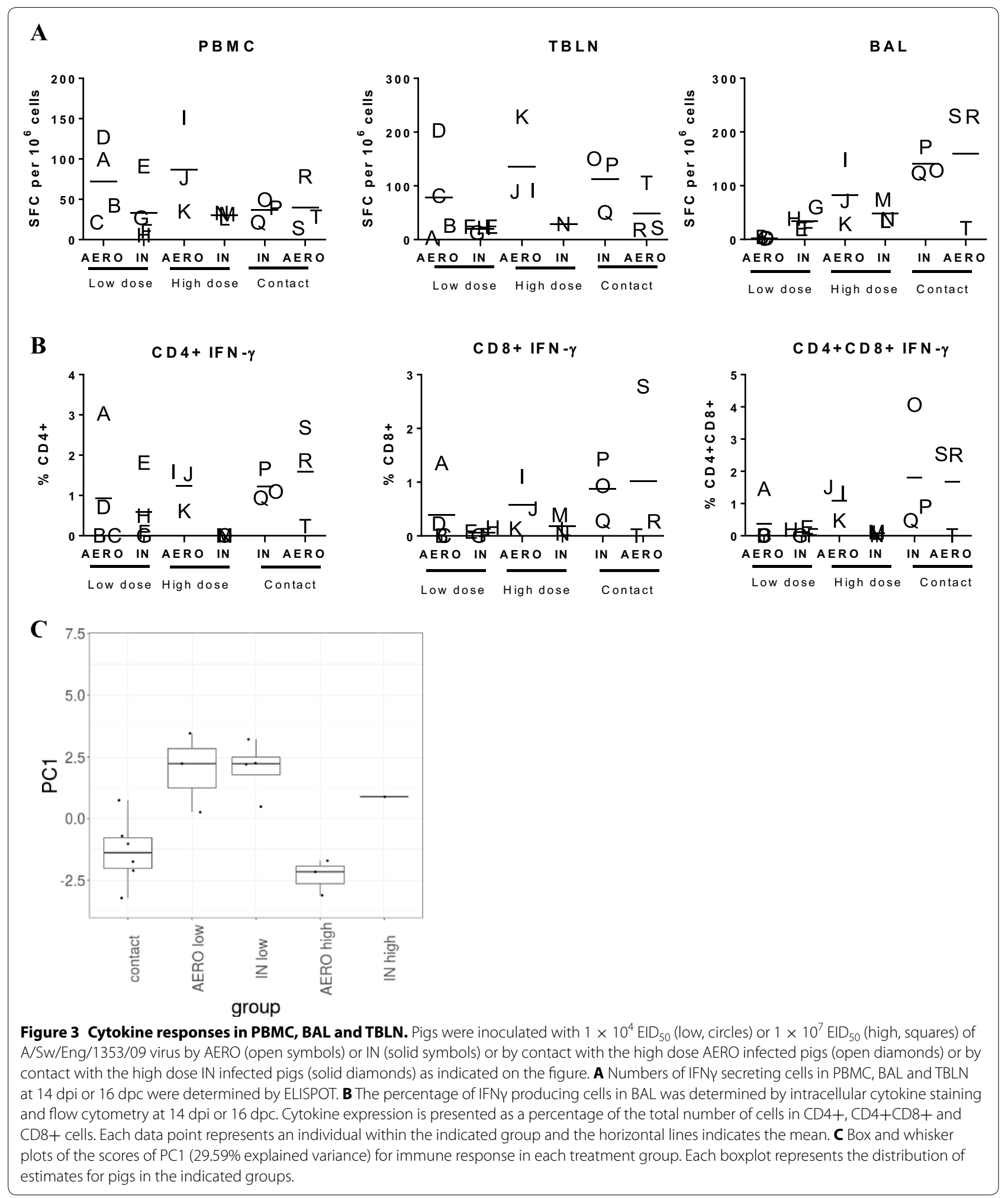

therapies, an understanding of the impact of the route of delivery is essential to allow comparison of data generated using different challenge models. Our results indicate that influenza A swine pH1N1 viral kinetics and immune response in naturally infected contact animals differ from those of animals experimentally infected by different 

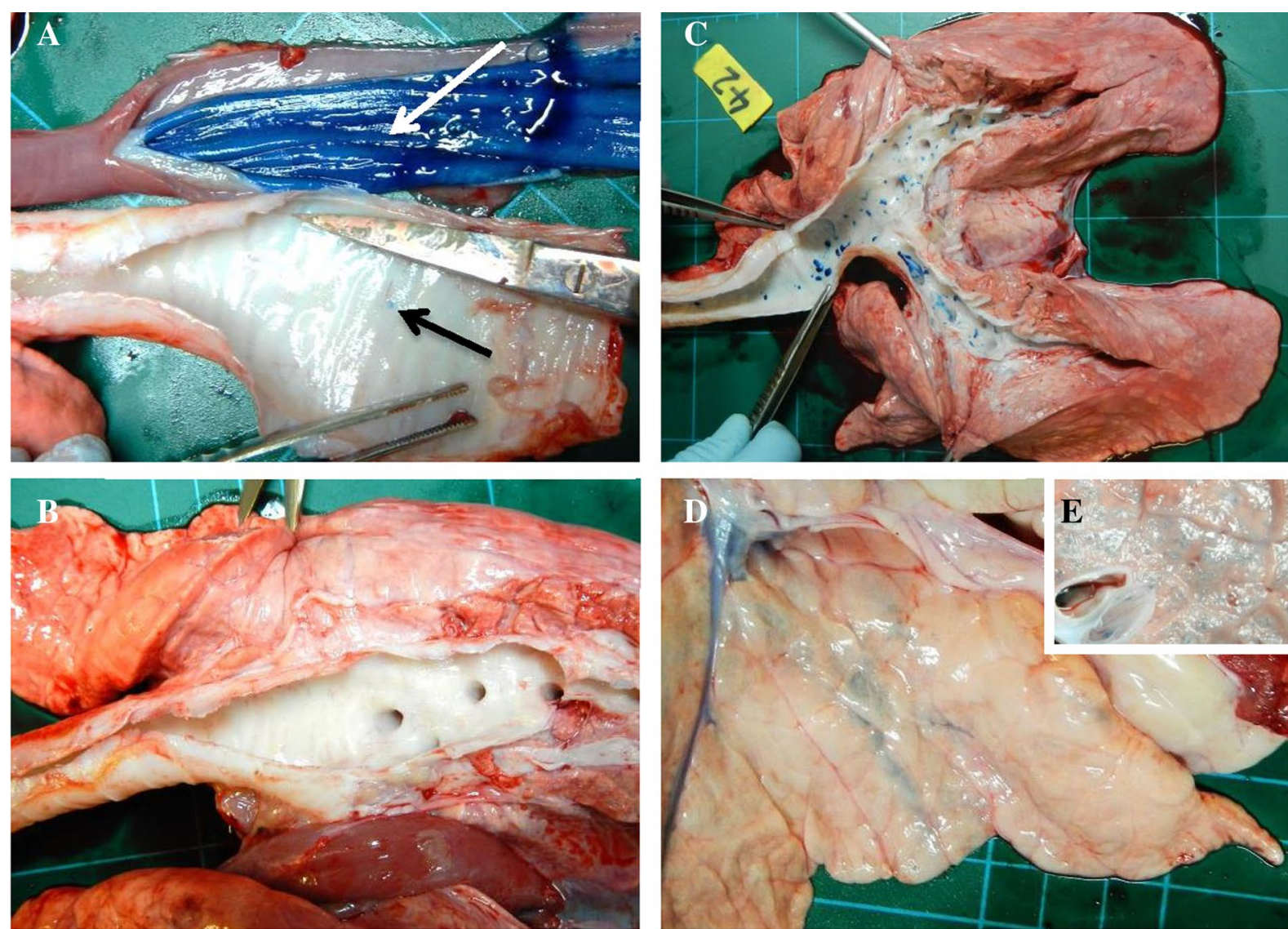

\section{$\mathbf{F}$}
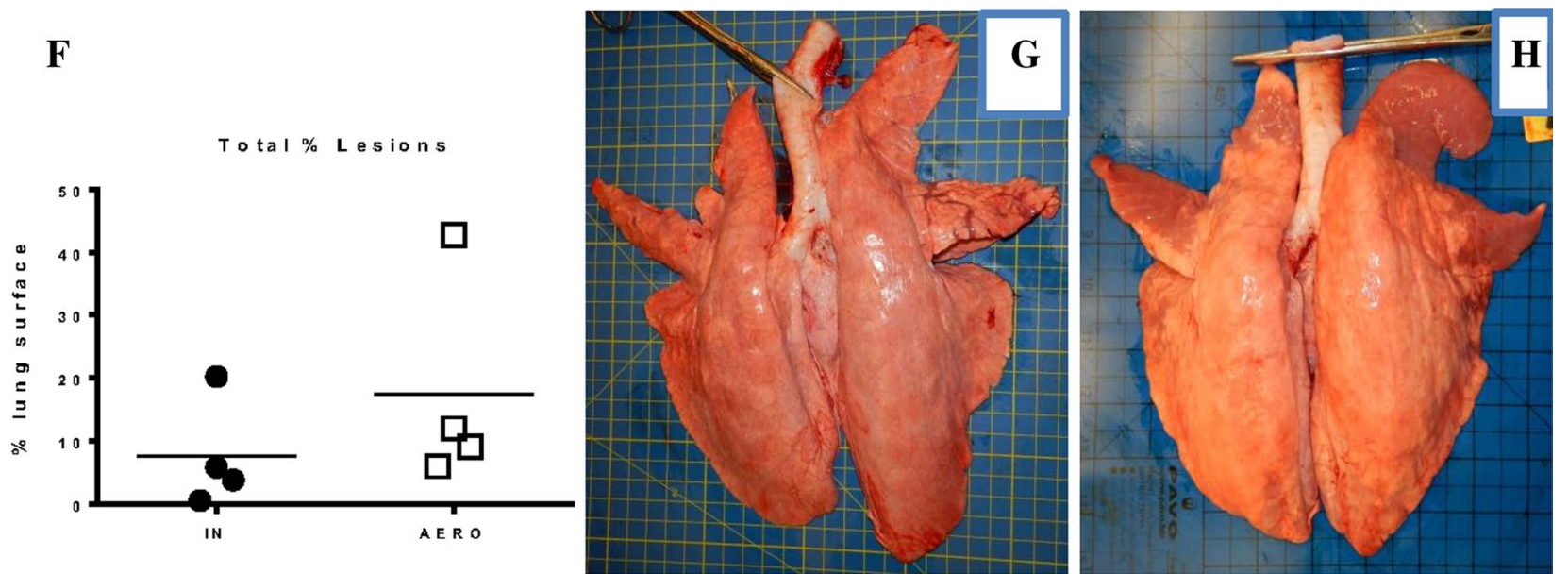

Figure 4 Distribution of Evans Blue and lesions in lungs. Groups of six pigs were administered Evans Blue either IN or by AERO. IN delivery of Evans Blue resulted in heavy staining within the alimentary canal (oesophagus, white arrow) and a very small amount in the upper trachea (black arrow) (A), no deposit in the lower trachea nor the rest of the respiratory tract or the lung parenchyma (B). AERO administration resulted in widespread distribution within the entire respiratory tract $(\mathbf{C})$ including the lung parenchyma as observed through the pleura (D) or after sectioning the lung $(\mathbf{E})$. The percentage of lung surface with influenza-like lesions varied in each animal with a higher score in AERO than IN (F). The distribution of lesions showed a small number of lung lobes with lesions in IN (G) compared to the majority of lung lobes in AREO (H).

doses and routes. In contacts, the kinetics of virus shedding were slow, prolonged and more similar to the low dose directly infected animals. In contrast the cytokine profile in nasal swabs, antibody and cellular immune responses of contacts more closely resemble immune responses in high dose directly inoculated animals. 
We also show that successful infection of pigs can be achieved with a much lower dose of virus by AERO than IN administration. Aerosol administration of influenza A virus to human volunteers demonstrates that fewer than ten virions can initiate infection and similar results have been obtained in the ferret model [21, 33, 34]. Additionally, influenza A virus in small droplets has been shown to be 100 times more infectious than influenza virus in large droplets [35]. Although IN challenge required a higher dose for successful infection, once infected, animals produced more virus and were better able to transmit infection, since all of the IN high contacts became infected. In contrast the animals given a high dose of virus by AERO did not transmit efficiently, suggesting that virus replicating in the LRT is more efficiently contained and less likely to be emitted than that in the URT. This is in agreement with transmission studies in ferrets, showing a significant correlation between virus titer in nasal washes and the likelihood of virus transmission, indicating that replication in the URT is the source of virus for both direct contact and airborne transmission [33].

Our results also demonstrate that natural infection is highly efficient in generating strong immune responses. Both innate and adaptive immune responses in the contacts are comparable to the responses in AERO and IN high dose directly challenged animals, yet viral kinetics indicate that the contacts received a low infectious dose. This paradox suggests that natural infection with a low dose is highly efficient in inducing an immune response and the response elicited is similar to that following experimental delivery of a high dose to either to the URT or LRT. We speculate that natural infection targets both the URT and LRT and therefore reaches the greatest number of antigen presenting cells and many lymph nodes, enabling the host to mount a strong and efficient protective immune response. On the other hand from the perspective of the virus, reaching the greatest number of receptor bearing cells gives it the best chance to infect and transmit.

In humans and ferrets aerosols of $<5 \mu \mathrm{m}$ are capable of reaching deep into the LRT and reaching alveolar tissues. Using Evans Blue dye we have shown that MAD delivery of $\sim 105 \mu \mathrm{m}$ droplets results in deposition in the URT and the digestive tract, while nebuliser-generated aerosol results in a wider distribution within the respiratory tree, including the lung parenchyma within the proximal and distal parts of all lung lobes. At first sight it is surprising that IN and AERO delivery which showed such different patterns of dye delivery, both generated strong immune responses. However this maybe because dye distribution does not represent what happens with infectious SwIV. As Figure 4F shows, pigs administered virus IN or by AERO both showed lung pathology. IN delivery by MAD is a widely used method for experimental pig challenge because of its technical expediency and many studies show that it is reproducible. We hypothesize that with MAD delivery of a high dose of virus sufficient material reaches the LRT to evoke an LRT immune response, although we and others have shown that the most efficient way to reach the LRT and induce an immune response is by aerosol [12, 36-38]. Further work using a larger group of animals will be required to confirm the differences in these readouts between IN, AERO and contact routes of infection.

In summary our data show that the inoculation method used for assessing immunity to SwIV and vaccine efficacy is critical in determining the outcome. High dose IN challenge results in a much higher virus titer in nasal swabs at day 1 compared to contact infected animals and it may be difficult to show protective efficacy, especially of $\mathrm{T}$ cell based vaccines, which do not prevent virus entry into cells. While contact infection may be optimal, it requires more animals and is consequently expensive. Low dose aerosol challenge may provide the next best alternative to natural infection. Our comparison of IN, AERO and contact infected animals shows that the route of infection and the dose of infectious virus may affect the outcome in terms of infectivity, viral shedding, immune response and pathology. Consideration of these differences is important for studies of disease pathogenesis and assessment of vaccine protective efficacy.

\section{Additional files}

\section{Additional file 1. Viral titre fits with a segemented linear regres-}

sion. Each box represent a challenge group. The dots represent the

observed viral titre, the solid line the best fit curve and the grey area best

fit curve \pm standard error.

Additional file 2. Bland-Altman plot comparing viral titre measured by PCR (REU) and by plaque assay $(\log 10 \mathrm{PFU} / \mathrm{mL})$. The solid line represents the average difference and the dashed lines the average difference \pm 2 standard deviations.

Additional file 3. Principal component analysis for IFNy ELISPOT, ICS and $\mathbf{A b}$ titers. PC loadings for PC1 and PC2 (PC2 was not significantly associated with treatment group) showing the amount of variability in PC1 and PC2 that can be explained by each variable. Intracellular cytokine production by PBMCs was positively loaded on $\mathrm{PC} 1$, while IFN- $\gamma$ production by cells in the ELISPOT assay was negatively loaded. BAL samples cluster together and are also negatively loaded. Antibody levels in BAL and serum correlate with IFN- $\gamma$ secretion by cells in the BAL and with IFN- $\gamma$ production by $\mathrm{CD}^{+}{ }^{+} \mathrm{CD} 8{ }^{+} \mathrm{T}$ cells in $\mathrm{LN}$.

\section{Abbreviations}

IAV: influenza A virus; pdm: pandemic; SwIV: swine influenza virus; MAD: mucosal atomisation device; LRT: lower respiratory tract; URT: upper respiratory tract; IN: intra-nasal; AERO: aerosol; HAl: haemagglutination inhibition; MDCK: Madin-Darby canine kidney; EID: egg infectious dose; FBS: foetal bovine serum; BAL: broncho-alveolar lavage; TBLN: trachea-bronchial lymph nodes; Ab: antibody; PFU: plaque forming units; PCA: principal components analysis; MRPP: multi-response permutation procedures; FPF: fine particle fraction. 


\section{Competing interests}

The authors declare that they have no competing interests.

\section{Authors' contributions}

$\mathrm{HH}, \mathrm{SM}, \mathrm{MA}, \mathrm{HE}, \mathrm{BVC}, \mathrm{KB}, \mathrm{SB}, \mathrm{IB}, \mathrm{BC}$ and ET designed and performed the experiments. LC, MCT and MW performed the statistical analyses of viral kinetics and cytokines. EP and MB performed statistical analysis of immune responses. FJS performed the pathological analysis and distribution of Evans Blue in the airway. RM designed the administration of Evans Blue and performed sizing of the particles. All authors read and approved the final manuscript.

\section{Acknowledgements}

This work was funded by the Biotechnology and Biological Scieneces Research Council sLoLa Grant BB/L001330/1. We are grateful to the animal staff at the Pirbright Institute and at the Animal and Plant Health Agency for excellent animal care. We thank Vivien Coward for technical assistance in the APHA labs. The challenge SwIV strain was characterised under Defra project SV3041 "Monitoring of influenza A viruses in the UK pig".

\section{Author details}

${ }^{1}$ The Pirbright Institute, Pirbright, UK. ${ }^{2}$ Virology Department, Animal and Plant Health Agency, Weybridge, Addlestone, UK. ${ }^{3}$ School of Veterinary Medicine, University of Surrey, Guilford, UK. ${ }^{4}$ School of Veterinary Sciences, University of Bristol, Langford, UK. ${ }^{5}$ Aerogen IDA Business park Dangan, Galway, Ireland. ${ }^{6}$ Centre for Immunity, Infection and Evolution, University of Edinburgh, Kings Buildings, Edinburgh, UK. ${ }^{7}$ Jenner Institute, University of Oxford, Oxford, UK.

\section{Received: 8 August 2016 Accepted: 30 September 2016}

\section{Published online: 20 October 2016}

\section{References}

1. Brown IH (2013) History and epidemiology of Swine influenza in Europe. Curr Top Microbiol Immunol 370:133-146

2. Rajao DS, Anderson TK, Gauger PC, Kitikoon P, Vincent AL (2014) Pathogenesis and Vaccination of Influenza A Virus in Swine. Curr Top Microbiol Immunol 385:307-326

3. Janke BH (2014) Influenza A virus infections in swine: pathogenesis and diagnosis. Vet Pathol 51:410-426

4. Watson SJ, Langat P, Reid SM, Lam TT, Cotton M, Kelly M, Van Reeth K, Qiu Y, Simon G, Bonin E, Foni E, Chiapponi C, Larsen L, Hjulsager C, Markowska-Daniel I, Urbaniak K, Durrwald R, Schlegel M, Huovilainen A, Davidson I, Dan A, Loeffen W, Edwards S, Bublot M, Vila T, Maldonado J, Valls L, Brown IH, Pybus OG, Kellam P (2015) Molecular epidemiology and evolution of influenza viruses circulating within European swine between 2009 and 2013. J Virol 89:9920-9931

5. Nelson MI, Vincent AL (2015) Reverse zoonosis of influenza to swine: new perspectives on the human-animal interface. Trends Microbiol 23:142-153

6. Smith GJD, Vijaykrishna D, Bahl J, Lycett SJ, Worobey M, Pybus OG, Ma SK, Cheung CL, Raghwani J, Bhatt S, Peiris JSM, Guan Y, Rambaut A (2009) Origins and evolutionary genomics of the 2009 swine-origin H1N1 influenza A epidemic. Nature 459:1122-1125

7. Rajao DS, Vincent AL (2015) Swine as a model for influenza A virus infection and immunity. ILAR J 56:44-52

8. Loving $C L$, Lager KM, Vincent AL, Brockmeier SL, Gauger PC, Anderson TK Kitikoon P, Perez DR, Kehrli ME Jr (2013) Efficacy in pigs of inactivated and live attenuated influenza virus vaccines against infection and transmission of an emerging H3N2 similar to the 2011-2012 H3N2v. J Virol 87:9895-9903

9. Babiuk S, Masic A, Graham J, Neufeld J, van der Loop M, Copps J, Berhane Y, Pasick J, Potter A, Babiuk LA, Weingartl H, Zhou Y (2011) An elastasedependent attenuated heterologous swine influenza virus protects against pandemic H1N1 2009 influenza challenge in swine. Vaccine 29:3118-3123

10. Brookes SM, Nunez A, Choudhury B, Matrosovich M, Essen SC, Clifford D, Slomka MJ, Kuntz-Simon G, Garcon F, Nash B, Hanna A, Heegaard PM, Queguiner S, Chiapponi C, Bublot M, Garcia JM, Gardner R, Foni E, Loeffen W, Larsen L, Van Reeth K, Banks J, Irvine RM, Brown IH (2010) Replication, pathogenesis and transmission of pandemic (H1N1) 2009 virus in nonimmune pigs. PLoS One 5:e9068

11. Lefevre EA, Carr BV, Inman CF, Prentice H, Brown IH, Brookes SM, Garcon F, Iqbal HMLM, Elderfield RA, Barclay WS, Gubbins S, Bailey M, Charleston $B$ (2012) Immune responses in pigs vaccinated with adjuvanted and non-adjuvanted $\mathrm{A}(\mathrm{H} 1 \mathrm{~N} 1)$ pdm/09 influenza vaccines used in human immunization programmes. PLoS One 7:e32400

12. Morgan SB, Hemmink JD, Porter E, Harley H, Holly H, Aramouni M, Everett HE, Brookes S, Bailey M, Townsend AM, Charleston B, Tchilian E (2016) Aerosol delivery of a candidate universal influenza vaccine reduces viral load in pigs challenged with pandemic H1N1 virus. J Immunol 196:5014-5023

13. Van Reeth K, Van Gucht S, Pensaert M (2002) Correlations between lung proinflammatory cytokine levels, virus replication, and disease after swine influenza virus challenge of vaccination-immune pigs. Viral Immunol 15:583-594

14. De Vleeschauwer A, Atanasova K, Van Borm S, van den Berg T, Rasmussen TB, Uttenthal A, Van Reeth K (2009) Comparative pathogenesis of an avian H5N2 and a swine H1N1 influenza virus in pigs. PLoS One 4:e6662

15. Vincent AL, Ma W, Lager KM, Richt JA, Janke BH, Sandbulte MR, Gauger PC, Loving CL, Webby RJ, Garcia-Sastre A (2012) Live attenuated influenza vaccine provides superior protection from heterologous infection in pigs with maternal antibodies without inducing vaccine-associated enhanced respiratory disease. J Virol 86:10597-10605

16. Masic A, Pyo HM, Babiuk S, Zhou Y (2013) An eight-segment swine influenza virus harboring $\mathrm{H} 1$ and $\mathrm{H} 3$ hemagglutinins is attenuated and protective against H1N1 and H3N2 subtypes in pigs. J Virol 87:10114-10125

17. Gauger PC, Loving CL, Khurana S, Lorusso A, Perez DR, Kehrli ME Jr, Roth JA, Golding H, Vincent AL (2014) Live attenuated influenza A virus vaccine protects against $A(\mathrm{H} 1 \mathrm{~N} 1)$ pdm09 heterologous challenge without vaccine associated enhanced respiratory disease. Virology 471-473:93-104

18. Pomorska-Mol M, Kwit K, Markowska-Daniel I, Kowalski C, Pejsak Z (2014) Local and systemic immune response in pigs during subclinical and clinical swine influenza infection. Res Vet Sci 97:412-421

19. Talker SC, Koinig HC, Stadler M, Graage R, Klingler E, Ladinig A, Mair KH, Hammer SE, Weissenböck H, Dürrwald R, Ritzmann M, Saalmüller A, Gerner W (2015) Magnitude and kinetics of multifunctional CD4 + and CD8 $\beta+$ T cells in pigs infected with swine influenza A virus. Vet Res 46:52

20. Marriott AC, Dennis M, Kane JA, Gooch KE, Hatch G, Sharpe S, Prevosto C, Leeming G, Zekeng EG, Staples KJ, Hall G, Ryan KA, Bate S, Moyo N, Whittaker CJ, Hallis B, Silman NJ, Lalvani A, Wilkinson TM, Hiscox JA, Stewart JP, Carroll MW (2016) Influenza A virus challenge models in cynomolgus macaques using the authentic inhaled aerosol and intra-nasal routes of infection. PLoS One 11:e0157887

21. Gustin KM, Belser JA, Wadford DA, Pearce MB, Katz JM, Tumpey TM, Maines TR (2011) Influenza virus aerosol exposure and analytical system for ferrets. Proc Natl Acad Sci U S A 108:8432-8437

22. Duerrwald R, Schlegel $M$, Bauer $K$, Vissiennon T, Wutzler P, Schmidtke $M$ (2013) Efficacy of influenza vaccination and tamiflu(R) treatment-comparative studies with Eurasian Swine influenza viruses in pigs. PLoS One 8:e61597

23. Slomka MJ, Densham AL, Coward VJ, Essen S, Brookes SM, Irvine RM, Spackman E, Ridgeon J, Gardner R, Hanna A, Suarez DL, Brown IH (2010) Real time reverse transcription (RRT)-polymerase chain reaction (PCR) methods for detection of pandemic (H1N1) 2009 influenza virus and European swine influenza A virus infections in pigs. Influenza Other Respir Viruses 4:277-293

24. Hibbitts A, O'Mahony AM, Forde E, Nolan L, Ogier J, Desgranges S, Darcy R, MacLoughlin R, O'Driscoll CM, Cryan SA (2014) Early-stage development of novel cyclodextrin-siRNA nanocomplexes allows for successful postnebulization transfection of bronchial epithelial cells. J Aerosol Med Pulm Drug Deliv 27:466-477

25. Slomka MJ, Hanna A, Mahmood S, Govil J, Krill D, Manvell RJ, Shell W, Arnold ME, Banks J, Brown IH (2013) Phylogenetic and molecular characteristics of Eurasian $\mathrm{H} 9$ avian influenza viruses and their detection by two different H9-specific RealTime reverse transcriptase polymerase chain reaction tests. Vet Microbiol 162:530-542

26. Muggeo VM (2003) Estimating regression models with unknown breakpoints. Stat Med 22:3055-3071

27. Benjamini Y, Hochberg $Y$ (1995) Controlling the false discovery rate: a practical and powerful approach to multiple testing. J R Statist Soc B 57:289-300 
28. Peres-Neto P, Jackson DA, Somers KS (2005) How many principal components? Stopping rules for determining the number of non trivial axes revisited. Comput Stat Data An 49:974-997

29. McCune GJ, Urban DL (2002) Analysis of ecological communities. MjM Software Design, Edinburgh

30. Petrie SM, Guarnaccia T, Laurie KL, Hurt AC, McVernon J, McCaw JM (2013) Reducing uncertainty in within-host parameter estimates of influenza infection by measuring both infectious and total viral load. PLoS One 8:e64098

31. MacLoughlin RJ, Higgins BD, Laffey JG, O'Brien T (2009) Optimized aerosol delivery to a mechanically ventilated rodent. J Aerosol Med Pulm Drug Deliv 22:323-332

32. Cowling BJ, Ip DK, Fang VJ, Suntarattiwong P, Olsen SJ, Levy J, Uyeki TM, Leung GM, Malik Peiris JS, Chotpitayasunondh T, Nishiura H, Mark Simmerman J (2013) Aerosol transmission is an important mode of influenza A virus spread. Nat Commun 4:1935

33. Varble A, Albrecht RA, Backes S, Crumiller M, Bouvier NM, Sachs D, GarciaSastre A (2014) Influenza A virus transmission bottlenecks are defined by infection route and recipient host. Cell Host Microbe 16:691-700
34. Alford RH, Kasel JA, Gerone PJ, Knight V (1966) Human influenza resulting from aerosol inhalation. Proc Soc Exp Biol Med 122:800-804

35. Ambrose CS, Coelingh KL (2012) Small-particle aerosolization of live attenuated influenza vaccine virus. J Infect Dis 205:348 (author reply 348-349)

36. Meyer M, Garron T, Lubaki NM, Mire CE, Fenton KA, Klages C, Olinger GG, Geisbert TW, Collins PL, Bukreyev A (2015) Aerosolized Ebola vaccine protects primates and elicits lung-resident T cell responses. J Clin Invest 125:3241-3255

37. Jeyanathan M, Shao Z, Yu X, Harkness R, Jiang R, Li J, Xing Z, Zhu T (2015) AdHu5Ag85A respiratory mucosal boost immunization enhances protection against pulmonary tuberculosis in BCG-primed non-human primates. PLoS One 10:e0135009

38. Low N, Bavdekar A, Jeyaseelan L, Hirve S, Ramanathan K, Andrews NJ, Shaikh N, Jadi RS, Rajagopal A, Brown KE, Brown D, Fink JB, John O, Scott P, Riveros-Balt AX, Greco M, Dhere R, Kulkarni PS, Henao Restrepo AM (2015) A randomized, controlled trial of an aerosolized vaccine against measles. N Engl J Med 372:1519-1529

\section{Submit your next manuscript to BioMed Central and we will help you at every step:}

- We accept pre-submission inquiries

- Our selector tool helps you to find the most relevant journal

- We provide round the clock customer support

- Convenient online submission

- Thorough peer review

- Inclusion in PubMed and all major indexing services

- Maximum visibility for your research

Submit your manuscript at www.biomedcentral.com/submit 